\title{
A Pragmatic Analysis of Proverbs in the Domains of Knowledge Construction in Igbo
}

\author{
Matthew Onyebuchi Ndiribe \\ Department of Linguistics, Igbo and Other Nigerian Languages, University of Nigeria, Nsukka, Nigeria
}

\begin{abstract}
The study examines the pragmatic analysis of proverbs in the domains of knowledge construction (KC). Knowledge construction is the process of creating of new ideas and understandings that are new to the discourse rather than the semantic implications. It is imperative that proverbs be surveyed to deduce these implications. The study used as its methodology, six respondents in the Faculty of Arts, University of Nigeria, Nsukka who were given the proverbs for analysis and they were requested to apply their own discretion in the interpretation of those data. In all, the work seeks to answer the question of 'how can knowledge construction (KC) be used in analysing of Igbo proverbs using pragmatic framework' and the objective of the study is to find out how $\mathrm{KC}$ could assist in bringing out the pragmatic nuances of the Igbo proverbs. The analysis will be carried out using some/all of the following four processes: interpretation, analysis, synthesis and evaluation. Finally, the study discovers that $\mathrm{KC}$ is deep rooted in contextual analysis as it is obvious that a particular proverb could have as many implications as possible based on the intuitions of the evaluators.
\end{abstract}

Index Terms-knowledge construction, pragmatic analysis, Igbo proverbs, speech act

\section{INTRODUCTION}

Knowledge is defined as the state of knowing about a particular fact or situation. Epistemologically, constructivists is a branch of philosophy of science which maintained that scientific knowledge is constructed by the scientific community who seeks to measure and construct models of natural world. According to constructivists, the world is independent of human mind, but that knowledge of the world is always a human and social construction. Based on the afore-mentioned, it is believed that knowledge is constructed based on personal experiences and hypothesis of the environment.

The role of learning theories explains the acquisition of knowledge but it does not adduce any importance to the ways of individualistic creation and construction of knowledge. This suggests that individuals are constantly active in constructing knowledge by means of their conscious and unconscious attempts.

Knowledge Construction (K.C) is an interdisciplinary concept. It is a process by which ideas and understandings are generated. Ideally, people construct knowledge when they apply critical thinking to go beyond knowledge reproduction by generating ideas and understandings that are new to them. This generation or thoughtful creation of new ideas and understandings lies at the heart of KC. By focusing on the process of creating ideas and carefully considering their values, one becomes more skilled at thinking critically and creatively. This is because learning involves constructing one's own knowledge from one's experience. Therefore construction process portends that our current knowledge influences what we learn, what we expect to learn, what we store and what we can retrieve (Ormrod, 2008).

When we encourage ourselves to generate new ideas, we are not concerned with how gigantic these ideas are; but we are more interested in the process by which we generate these ideas. The process gives more opportunity to construct ideas, connect them to other content and then internalise the outcome understandings (www.wcsd21). The process of generating ideas typically includes one or more of the following:

(a) Interpretation: that is, the means of drawing inferences beyond the literal meanings

(b) Analysis: this means identifying relationships among the parts of the whole

(c) Synthesis: that is, the means for identifying relationships among two or more ideas; and

(d) Evaluation: that is, the means for judging the quality, credibility, or importance of data, ideas or events.

In this study, efforts would be made to incorporate the various processes enunciated above in the handling of our data. This presupposes that the whole processes might not be employed in a particular data but that each process is evoked when it addresses the particular data under consideration.

Proverb, on the other hand has its seat at the heart of pragmatics. This is why the Igbo people consider proverb as a mature knowledge for a mature conversation. The use of proverb is the mark of mature speaker. It is often used to begin address, especially when one aims at making an impressive and powerful speech before audience of respectable, experienced and elderly people who can easily decode exactly what the speaker intended. This is where KC comes in because the addresser and the addressee must be on the same page in the discourse domain, else, there will be distortion in meaning which automatically destroys the KC.

Proverb, though a property owned by Igbo people in general has its own dialective values, hence the saying "Ndi banyị sịirị” 'our people say' (cf Ndiribe, 2015). This dialectic value helps in KC because even the critical thinking 
aspect of $\mathrm{KC}$ is done in one's dialectic persuasion. The Igbo man quotes proverbs to buttress his points and give authority and authenticity to an idea or a disputed fact. Proverb is a way of putting a bitter truth through the medium of smooth words. The wise listener must be clever enough to do his $\mathrm{KC}$ and come up with the intended meaning that the speaker supposes. Proverbs are highly figurative, and as such, they have high forms of linguistic sophistication. This is where the processes of interpretation, analysis, synthesis and evaluation are needed for the listener to be at the same page with the speaker. The need to acquire the ability to understand and use proverb is the ability to do a comprehensive $\mathrm{KC}$ and the need cannot be overemphasised.

This study seeks to answer the questions of "how can the knowledge construction (KC) be used in the analysis of Igbo proverbs using pragmatic framework and the objective of the study is to find out how KC could assist in bringing out the pragmatic nuances of the Igbo proverbs.

Igbo language belongs to the West Benue-Congo in the Niger Congo language family. Igbo language is spoken in Abia, Anambra, Ebonyi, Enugu and Imo states as core states in the South-East region. It is also spoken in some parts of Bayelsa, Delta and Rivers states as 'non-Igbo states' all in the South-South region of Nigeria. By being non-Igbo states, the three states of Bayelsa, Delta and Rivers have other languages apart from the Igbo language which form a tiny part of the conglomerates of languages spoken in this region. The South-South region has linguistic importance because of its multilingual nature. The number of speakers, according to Williamson \& Blench (2000) in Mbah (2007) is about 15 million. But the 2006 Population Census put the South-Eastern states figures at 16,381,229 million. That is, Anambra $(4,182,032)$, Imo (3,257,298), Enugu (3,934,899), Abia $(2,833,999)$, and Ebonyi $(2,173,501)$. This is excluding Rivers $(5,185,400)$ and Delta $(4,098,391)$. All together, the population is well above 25 million speakers (NPC 2006). It has a number of dialects, of which Ihiala and Nsukka are one of them, which are to a large extent mutually intelligible.

The study is further organised in this fashion:

Section two deals with definition of terms and literature reviews under pragmatic framework, section three looks at the methodology adopted in this research, section four highlights the proverbs under discussion and analysis using the processes enumerated above; section five chronicles the implications of $\mathrm{KC}$ to the analysis of Igbo proverbs using the pragmatic framework while section six does the summary of the work.

\section{DEFINITION OF TERMS AND Literature REVIEW}

There are several approaches to the analysis of discourse, which include speech act theory (SAT) which could be either direct or indirect (Ndiribe, 2016; Enwelum-Nkem. p. 2017) and pragmatics. In SAT, the focus is on what social function the speech would have on the listener, whereas in pragmatics, the focus is on the context that necessitates the speech. In the Igbo language, proverbs have both social and contextual implications. This accounts for the reason why unmatched proverbs are frowned at whenever they occurred. Since we perform actions as we use language, those actions must match the context and intention for which they are made. This is why a proverb must be seen to fill all the above gaps.

\section{A. Speech Act Theory (SAT)}

(Ndiribe. 2016, p. 236) asserts that the development of SAT is credited to the Oxford Philosopher, J.L. Austin. There are a lot of controversies as to who really was the author of speech act theory. Saeed (2003) is of the opinion that SAT was published posthumously by Austin's students in 1975, Courthard (1985) believes that the work was published by Austin himself in 1962. Mey (2001) and Yoshitake (2004) also maintain that the work was published by Austin himself in 1962. However, all the various scholars agree that the work was published with the title: "How to do things with words" and this is where context came in.

The concept "speech act" rests solely on the assumption that the meaning of an utterance is its intended social function. That is, the act of learning to communicate in a language involves more than acquiring the pronunciation and grammar of the said language. In other words, the initiator of the framework believes that we perform an action whenever we use language. In speech act, the disciplines of both semantics and pragmatics are explored to bring out both literal meanings and the intended meanings.

\section{Direct Speech Act}

Yule (1996) asserts that when the form such as 'Did he?..., Are they?...or Can you?... is used to ask a question, it is known as a direct speech act. He also maintains that when a speaker does not know something and asks the hearer for the information, s/he will typically provide a direct speech act.

\section{Indirect Speech Act}

(Yule. 1996, p. 133) goes on to say that some utterances which look like questions are usually treated as requests to perform some actions. He describes this type of questions or constructions as indirect speech act. (Searle. 1975, 61) buttresses the concept of indirect speech act thus: Suppose somebody says to a friend: let's go to the movie tonight and the friend answers: I have to study for an exam. What is this friend trying to tell his/her interlocutor? And how do we know that the second utterance in fact is a rejection of the proposal contained in the first while seeming to be completely unrelated to it and not containing any overt or hidden expression of negation or rejection; or even a mention of rejected offer? 
Searle views indirect speech act as a combination of two acts, that is, a primary illocutionary act (in the example above, rejecting a proposal), and a secondary one (in this case, making a statement), where the primary act through, and in force of, the secondary one.

\section{B. Pragmatics}

Historically, the term 'pragmatics,' according to Enwelim-Nkem (2017), can be traced to Morris (1938), who perceived pragmatics as a two-fold concept of syntax-semantic interface that is embroiled in a terminology known as 'pragmatics'. (Levinson 1981, p.1) in (Enwelum-Nkem. 2017, p.521) "in Morris explanation of these three branches of inquiry, syntax is taken to be the study of "formal relation of sign to one another", semantics is the study of the "relations of signs to the objects to which the signs are applicable" and pragmatics, the study of the "relations of signs to interpreters".

Pragmatics is the aspect of study which, according to (Ndiribe. 2015, p. 51) is a subfield of linguistics which seeks the ways in which context contribute to meaning. The meaning is not derived solely from the meaning of the words used in the sentences. The meaning is far-fetched from the combination of the words or phrases which make up the sentences (cf. Robinson. 2006).

Pragmatics is the study of the speaker's intended meaning, not focusing on the phonetic or grammatical meaning, but instead on what the speaker intention and belief are (cf. Dijk, 1977). Accordingly, Carson (2002) sees pragmatics in linguistics as the meaning in context, and the influence that a given context could have on the message. This, according to Carson (2002), requires the knowledge of the speaker's identity and place and time of the utterance. Grice (1989) is of the opinion that pragmatics is the study of implicature, i.e. the things that are communicated even though they are not explicitly expressed, while Thomas (1975) discusses pragmatics in language use as the study of relative distance that is both social and physical between speakers in order to understand what determines the choice of what is said and what is not said. Varschuren (1999) on his own part aligns pragmatics with the study of what is meant as opposed to the intended meaning, i.e. that which is unsaid and unintended or unintentional.

Robinson (2002) uses information structure to analyse pragmatics. To him, pragmatics is the study of how utterances are marked in order to effectively manage common grounds of referred entities between speakers and hearers. It encompasses speech act theory; conversational implicature; talk in iteration and other approval to language behaviour in philosophy, sociology and linguistics (cf. Austin, 1962). Unlike the semantics which examines meaning that is conventional in a given language, Brown and Levinson (1978) see pragmatics as one that studies how transmission or meaning depends not on structural and linguistic knowledge, e.g. grammar, lexicon etc. of the speech listener but also the context of the utterance, any pre-existing knowledge about those involved, the inferred intent of the speaker, and other factors. In this respect, pragmatics explains how language users are able to overcome apparent ambiguity, since meaning relies on the manner, place, time etc. of the utterance ( Mey, 1993; Clark, 1996).

As an ideal Igbo speaker, when we hear some proverbs, we normally try to understand not only what words mean, but what the writer or speaker of those proverbs intends to convey (Ndiribe, 2015). According to Yule (1996), "pragmatics is the study of intended meaning". Accordingly, (Courthard. 1985, p.50) sees conversational analysis as a first step towards achieving a "naturalistic observational discipline to deal with details of social interactions in a rigorous, empirical and formal way". (Bell. 1991, p. 112) sees a language context as the one which can be recognised by knowing insider who can bring the brute fact together as social facts. He goes on to assert that the specification of the context of utterance can, unlike the description of the situation, be much more implicit since it assumes the totality of the shared knowledge possessed by the participant in the communicative act.

These brute facts and the specification of the context of utterances are the seat of proverbs in Igbo. For one to be in tune with the rhythm of communication, one must be able to engage oneself in knowledge construction in order to decipher these brute facts.

\section{Igbo Proverbs: A Theoretical Perspective}

Proverbs are oral compositions and their various stylistic constituents are derived from all layers of what we described as the hierarchy of socio-cultural value systems of the people. They point to the individual, domestic and collective life pattern of the society from which they are derived. In other words, proverbs adopt material from peoples' environment. (Obiechina. 1975, p.156) perceives proverbs as "a collection and/or representations of people's way of life". Obiechina's observation is quite obvious because in any proverb one is likely to see the culture of the people that own the proverb.

Proverbs actually come from the depth of tradition, reflecting the intellect and wisdom of the people. Proverbs in Africa, are wise sayings and, a special prerogative of the elders. The elders are always exalted as the custodians of the wisdom in Africa. Any African elder that lacks this power of the mind and words may lose his respect, no matter his importance in the society. (Nwoga. 1976, p.83) says that" a proverb is the wisdom of many and the wit of one; the experience and wisdom of several ages gathered and summed up in one expression; and the edge tools of speech."

Two things are clear about Nwoga's definition. First, proverbs make speech to be short, in other words, it is an economic way of using words. Secondly, proverbs bring out the wisdom and tradition of the people. 
(Abraham. 1964, p.61) in his own words defines proverbs as "the aphoristic saying enjoying traditionally handed down currency...having protean powers of interpretation". The protean powers of interpretation may enjoy a certain universality of application, but essentially proverbs reveal the culture in which they exist.

\section{Empirical review}

Igbo proverbs are useful in speech because they cover the entire range of human existence. Igbo proverbs describe a wide variety of natural occurrence and give a characteristic analysis of historical events.

Nwadike (2009) collected 85 Igbo proverbs and classifies them into 36 sub-headings. Some of these proverbs have literal meanings as well as explanations while others are coloured in their literal meanings only without any further explanations. Nwadike (2009: 35) has this to say under admonition:

(a) $O$ bu mmiri a gba oso

S/he carry water Neg run run

'One who carries water needs not (cannot) run'.

It means: one in a position of trust should not be found wanting. It can also mean that those who live in glass house should not throw stone.

In (p.56) under love, we have the following:

(b) Iwe nwanne a na ghi e ru n' okpukpu

Anger sibling imp. Aux. Neg. Imp. reach Prep bone

'Anger for a blood relation does not get down to the bone'.

(c) Aso nwanne a na ghi a gbuli ya elu

Saliva sibling imp. Aux. Neg. Imp. push it up

'Saliva splitting on a blood relation is not raised high'.

Under fear he has this:

(d) Nkume rịa elu, ụjọ atụwa ite mmiri

Stone climb up fear come pot water

'When the stone climbs up, fear grips the water pot'.

Though this work by Nwadike (2009) shows various proverbs of Igbo world view, it is purely literal. It enhances this present study in the sense that it lists the types of proverbs in Igbo language and the categorisations of such proverbs but it differs with this present study in the area of context. The pragmatics of proverbs is what motivates this present study.

Ndiribe (2015) studies proverbs as they relate to image schemas in Igbo. He analyses nine proverbs and discovers that Igbo proverbs support some concepts of image schemas like path, force, containment/container and causal schemas. He concludes that the schemas like force, containment and path are contained in some proverbs but maintained that the image schemas used in the study do not constitute a closed set. This present study uses proverbs to ascertain the domain of knowledge construction in the Igbo language. Therefore, my preoccupation here is basically the domains of knowledge construction (KC).

\section{Methodology}

The researcher put down the proverbs for consideration and then sent them across to the appropriate respondents.These respondents were adults that were over forty years of age. These respondents were six in number and were selected from both academic and non academic in the faculty of Arts, University of Nigeria, Nsukka. Among these six respondents, three were males while the other three were females. These proverbs for the analysis of this study were sent to them and their knowledge constructions of those proverbs were elicited based on the interpretations they assigned to the proverbs.

\section{DATA PRESENTATION AND ANALysis}

In this section, efforts will be made to present the proverbs which form our data for analysis and then analyse them in line with knowledge construction criteria.

1. Dibịa ụlọ a na ghị a gbata ọkụkọ

Doctor house imp. Aux. Neg imp. shoot fowl

'Home/family doctor does not get a fowl'.

In the traditional healing method, a doctor or a seer is known to be asking his clients to bring a fowl for the jobs or activities he performed for the clients. The clients provide the fowl without any objection as their objection may attract the wrath of the gods which these doctors represent.

The interpretation of the proverb is that the family or village artiste does not perform wonders to the members of the family or the community. Why should they accord him any respect even to the extent of obeying him and paying him any homage. Because he is a member of the family or the community, there is a look down on his person and on his ability to perform any wonders.

The analysis of the proverb above is that there is a great disregard not because of performance inability but because of the person of the performer. But does it mean that others outside the given area do not value or recognise the same person? They (the family members) equally share in the fortune he makes from people outside who believe in his ability. 
The fact is that these people see outsiders who patronise this rejected person of theirs as people who are deceived into believing falsehood. The home doctor is not regarded just because he is a home doctor. People who disregard him are his contemporaries - those who grow up with him, at times, they know his family background; his childhood activities and the general information about his parents. So how should they honour such a person who they know inside out ?

The $\mathrm{KC}$ here is that people are depriving themselves of valuable substances which the neglected home doctor possesses. The KC is summarised as that of 'over familiarity brings contempt'. The $\mathrm{KC}$ goes ahead to ascertain that the home doctor can never enjoy the goodwill of his people.

2. Anụ ụlọ a na ghị a cha nkịta anya

Meat house imp Aux Neg imp. worth dog eye

'Home animal/meat is worthless to the dog'

The interpretation of the proverb is that the animal/meat is worthless before the dog because it is from within the environment. This explains for why the home-made goods are neglected by the people. How many people patronise home made goods in the presence of foreign made counterparts? It is not because the home made ones are inferior but because it is locally made. If the people patronise the locally made goods which are less in price, then it would seem to them as spending their money on worthless things.

The analysis is that the people will not appreciate what they have because those things do not cause them any fortune. But if they use greater resources to obtain that same quality elsewhere, then their quest for better thing is satisfied.

The KC would like to know why people should discard what is relatively available to them only to go out in search of a similar thing. So why should people despise offers within their places and then go to other places and beg for the same thing they rejected back home? Why should people patronise goods that are made in China, Niger, Chad, Cameroon as against the ones made in Nigeria? Why is it that people do not complain when they purchase other countries made goods which do not last for them but to shout from a roof-top when locally made goods has the same quality? The locally made goods are referred to as Igbo-made. Why do we like to import everything even agricultural products from other countries when we have great arable lands for cultivation with great fertility. We despise everything that the Almighty God has endowed us with.

3. Nwaanyị na- a mụ nwa n’ ahịa a na ghị a kpachi ụkwụ
Woman Aux Pref. born child Prep. market Imp Aux Neg Pref. Cross leg

'A woman that delivers in a market place does not cross her legs'

The interpretation of the proverb is that there are things one cannot do not because one does not want to do them but because one has no power of his own to do them. A woman would ordinarily not desire to put to bed in a market place because a market place is not the ideal place to deliver of a baby. Since the desire to deliver is not one of the deliverer, the deliverer has no option than to deliver even in the so called unconducive environment.

The analysis of the proverb is that the force of nature cannot be postponed. Whether the deliverer wishes to do it in the place is immaterial because the force associated with the delivery will not permit the deliverer to make a suggestion. Since labour is a spontaneous action, it does not give the deliverer the opportunity to suggest how and where the delivery will happen. If the deliverer decides to do otherwise, she will be ready to accept the consequence which is death to her and the unborn baby.

The KC would want to know why a woman would debase her sanctity in a market place. The answer is that it is a matter of life and death. It is a matter of 'can't help'. Because it is a matter of 'can't help', the deliverer will ignore her personality and align herself with the call of nature. This explains for why it is impossible to see a woman that is sleeping during labour.

On the other hand, when a man is desperately in need of anything, he will go all the way to get it no matter the humiliating process it might entail. What is of paramount important is that the demand is achieved. Whatever it takes to achieve a desired goal is more than the process by which the desired goal is achieved.

4. Nwa nnadi ma ụma awa ọgọdọ, onye ọbụla mara otu amụ ibe ya ha

Child kinsman know vain tie cloth, person all know how penis other his is

'The kinsman ties the cloth in vein, everybody knows the size of others penis'

The interpretation of the proverb is that the greatest enemy of a person is that of his household and kindred. The bible says that a prophet is without honour and respect but among his kinsman. There is no smoke without fire and a stranger cannot hurt anyone if the insider is not a collaborator. It shows that the insider seems to know more of his neighbour than the outsider.

The analysis of the proverb depicts that the insider is always there to monitor and is also there to give account of what $\mathrm{s} /$ he knows about her/his colleagues. Knowing the size of one's penis means that one should not perform wonders before his/her people when they do not see anything out of ordinary. They also show their surprise and apprehension. Some will monitor the person for some time to know whether what they saw of him/her is real or pretence.

But, the KC would dig deep to know whether the concept that 'the only thing that is constant is change' cannot operate in this situation. How can people claim to know everything about an individual? The evaluation is that the information one has about an individual in the past can never be trusted to be authentic in all situations. Man is not created to be 'all knowing' and it is impossible for a mortal being to assume the position of God. This accounts for why there is always disappointments when what we think about happened in the exact opposite way. 
5. Onye hụ rụ otule diochi a na ghị e nwe mmasị ị nụ mmanya o tere

Person see Past anus tapper imp Aux Neg Inf. have like inf drink wine $3 \mathrm{~S}$ tap

The person that saw the anus of the (wine) tapper will not like to drink the wine (he tapped)

Once a person's ill motivated behaviour is discovered, the person losses his value. The interpretation is that those who command respects should do everything to maintain status quo and never at any time betray the confidence the people have on them. This is because the moment the people discover that they fall short of their expectation, then they will have no more confidence in their abilities never to disappoint them. The implication is that once the led or the followers lose confidence in their leaders, they will have no further business with such leaders. The leader is like a salt that lost its savour and will be useful for nothing.

The analysis of the proverb is that it is better for people to keep to the standard for which people rate them and maintain the integrity as long as they have something to do with the people. Failure to maintain the integrity will erode the personality of the people. Once the people turn their back on the failed leader, it will be very difficult, if not impossible for such a leader or the person to woo those people back.

The $\mathrm{KC}$ would like to ascertain why the exposure of the anus of the tapper is more important than drinking the wine that the tapper produced. The discovery shows that people will first and foremost consider the individual first before they consider what the person has to offer. That is, the container before the content. But is there no room for amendment? Even though there is a room for amendment, the fact remains that the amendment cannot restore any damaged thing to its earlier state. This presupposes that many people who might have left because of the first blunder may not find the courage to come back.

6. E rue nwoke ụlọ, a mata onye ọ bụ

Imp. reach man house imp know who he is

'A man's worth is determined when you get to his house'

This means that people should not be evaluated on the superficial outlook alone. The reason is that many people pretend so much when they are outside their domains. Many try to deceive others by their physical outlooks. Some will even go as far as hiring a nice car to an occasion in order to deceive people.

The analysis of the proverb is that whatever a man carries with him outside is not any tangible thing as to access his worth. For instance, if a man wants to borrow money from a bank, the bank will require a fixed property or collaterals. These fixed properties include land, house or good certificates. These requirements are not something he can produce in a transit but will demand that the borrower gets to his house. A person who wears good clothes without the fix property will never be considered by the bank for that transaction. The implication of the proverb is that 'not all that glitters is gold'. So before evaluating a man, one should try to get both the inside and the outside of the person so as to get a thorough evaluation of the person.

The KC discovers that people claim what they are not in order to conceal their personality. This concealment could be either positive or negative. For instance, a fraudulent person would want to be accessed by his present outlook and whenever one wants to go further he feels uncomfortable. Some wealthy people will appear so humble in the eyes of the public and will never want the public to know who they really are for fear of their safety. Based on the afore-mentioned people should look before they leap.

7. Ihe okenye nọrọ ala hụ, nwata rigoro elu ọjị o ga ghị a hụ ya.

Thing elder sit down see, child climb high iroko s/he Aux Neg Pref see it

'What the elder sees while sitting down, the child will not see it even if he climbs an iroko tree'.

This means that experience cannot be bought in the market. There are things that cannot be acquired with money or with rush. This shows that experience grows like an old age. The more one is experienced in any act of life, the more he is effective in that act. This accounts for why experience is demanded in every aspect of human endeavour. In the football pitch, the experienced players struggled the least and achieved more results than the inexperienced players who did all the running and attacks and achieved less. The inexperienced wasted a lot of time and material resources unlike the experienced who are circumspect in everything and thereby saved a lot of energy and resources.

The conceding of defeat by the former President Goodluck Ebele Jonathan (GEJ) in 2015, when he had, as a sitting president, all the privileges of the state powers is one example which is very hard to appreciate. People called him all manners of names like clueless, lazy and timid president. But he understood that he was the only person at the time that held the unity and disintegration of the country in his hands. For him to choose the unity and lives of his people he must relinquish the power by accepting defeat, else he chose the disintegration that would be heralded by wanton killings and destruction of property by rejecting or cancelling the outcome of the result.

The young people especially those from the southern Nigeria would see no reason at all for the president to act in such a cowardice manner when it was obvious to them that the election was rigged by a northern umpire to favour a northerner.

The analysis of the proverb portrays that experience grows with self-convincing. People that are clamouring for the actualisation of Biafra Republic today are mostly youths who were born some decades after the end of civil war in Nigeria. They did not witness how people were massacred in the war. They did not witness how children died of kwashiorkor because of the economic blockade carried out on a particular divide. No elder in the house would be supportive of the call about the realisation of the Republic of Biafra. 
The $\mathrm{KC}$ believes that experience comes with maturity. It portrays that people tend to be professional as they continue to engage themselves in a particular venture. Conclusively, $\mathrm{KC}$ argues that people should learn to spend quality time in their chosen fields of endeavour in order for them to give their best to the society. Wastages should be minimised when people are placed according to their expertise. Putting the square pegs in the round holes should be discouraged if we expect to get the best. Finally, the young shall grow but the young should be sure that he is growing with the efficient tools that can help in the nearest future.

8. Ónyé ífòrífó a ma ghị mgbe e kere nkụ ụkwa Person stupid Pref. know Neg. when imp. share firewood breadfruit

'The stupid person (a fool) does not know when they share the breadfruit firewood'

The meaning of the proverb is that one who is not articulate when things are done rarely understood what was done. For one to benefit from a struggle, one must participate in the struggle. One should not leave anything to chance with the notion that 'it will be resolved'. If somebody encroaches into someone's property, the owner of the property must do something to show the trespasser that he is alive to his responsibility else, the encroacher will have a free ride.

The analysis of the proverb is that those who think that they are wise by keeping silent when a serious issue is being discussed later discover that a serious decision which affected them was taken in that discussion. These set of stupid people will go on afterward to insinuate that they are marginalised in the group because of their race or ethnicity or religion. These set of people are always lost and would want the hand of the clock to be turned anticlockwise only for them to discover that a clock was not made to move that way.

The KC would want to ascertain how the breadfruit firewoods are shared. Could it be that people came and some people started appropriating some logs to themselves whereas others are docile waiting for the time a call would be made for all to come to the sharing of breadfruit firewood? Only for them to realise that what each person appropriated to himself belongs to him. Those who are waiting for a call to start sharing realise that the whole thing had been shared up.

The $\mathrm{KC}$ advices that one must act when others are acting to avoid being taken unawares. A lot of opportunities occur once and again but only the ones that are ready to hold the bull by the horn make good use of the opportunity.

The conclusion is that anyone who fails to act while the action is necessary is regarded as a foolish person. What one looses by one's indecision to act might not be recovered in one's life time.

9. Nwátà ma ụma agba egwu aja, okenye nwe anụ

Child know vain dance beating sacrifice, adult have meat

'The child is dancing the dance of sacrifice in vain, the meat belongs to the elders'.

The meaning of the proverb is that formality will always remain a formality no matter the seriousness one attaches to it. No matter how serious a child attaches to the music of the sacrifice that can never in any way confer the ownership of the meat of the sacrifice to him.

In the traditional Igbo setting, the young men do the dancing of the masquerades, yet the proceeds of that activities go to the elders who were seated somewhere. Some youths, out of zealousness, go contrary to the rules of the masquerade and as such got reprimanded through a commiserate fines that range from bottles of wine to a full grown cock or goat depending on the severity of the offence. In all the activities, the youths do not get any positive rewards from the elders.

In politics, the illiterate youths are the tools for electioneering for the elites. They did all the thuggery with the promise of better package. Their activities end the moment election was won and lost. Some of these people (youths) even see their principals appointing people from the opposition to occupy important positions.

The analysis is that no matter how hard an illiterate works in the cause of any action, he is used to achieve an effect that would probably exclude him outrightly in the long run. No matter how vigorously an illiterate youth work for a politician, the politician can never make him a minster, or commissioner or even special assistant in his government. The elites who did not participate in the electioneering campaigns are invited to come and take up position based on their expertises.

So why should people take so serious to activities they should not be partakers later on. Why should people lose their lives while they are projecting an entity that will later reject them and dump them by the side of the road? The KC would want to interrogate whether there is anything these youths could do for them to be part of the meat at the end of the dance. The KC discovers that their youthfulness do not qualify them and then advises them to keep away from the dance or dance as a hobby without having any hope of reward at the end. KC maintains that they would be highly disappointed if they think that the dissipation of their energies for these elders and politicians would fetch them anything afterwards. These disappointment leads to frustration which in turn leads to various vices we see today in our country.

10. A ga- e ru nti nso tupu a maa ya ọra

Imp Aux. Pref. reach cheek close before imp throw it slap

'One must get closer to the cheek before one slaps it'

There are things that are not possible if one is not involved. Before one could do anything, he must be updated in the process or the activity. No one can burgle another person's house if the person is not detailed about the house by an insider, else the close relative must be the one to do the burgling. It is he who knows a person that kills him. 
On the other hand, one should not comment on certain activities if such a person is not a member. The best way to contribute to a debate is to belong to the debate group and use the opportunity of membership to contribute. For instance, if one wants to change the bad leadership of any country or state, the person must belong to a political party for him to contribute. But if the person concludes that politics is a bad game, the same person should be contented with the type of leadership he receives. His belonging to a political party does not guarantee him an expressway to becoming a leader but it affords him the opportunity to make some useful suggestions and contributions and in so doing becomes the spokesperson for those who receive the impact of the bad leadership.

The KC would like to ascertain why it is important that one must be close to the cheek before one could slap it. The answer is that one who is afar of cannot manufacture a longer hand in order to reach the cheek of the person in question. As a matter of the quest to slap the cheek, the person must strive to be close to the cheek.

To get closer might take an extensive planning as to how and when. For instance, if the target has security details around him, how could the planner get closer to him? This entails that the planner will device a means which could be either positive or negative. The most important achievement is that he gets closer to the target and finally slaps him. Slapping him is regarded as meeting his target and not necessarily getting closer to him.

By this, anyone who gets closer to the cheek and fails to slap it because of fear, intimidation or respect in this instance is adjudged a failure. The KC would like to know why it is necessary to slap the cheek. The answer is that the necessity of slapping the cheek forms the objective of getting closer to it in the first instance and any failure to achieve this would be catastrophic.

There are two activities here: getting closer to the cheek and then slapping it. These two requires proper planning and proper execution. The outcome of this proper planning and execution is immaterial. For instance, the coup that killed General Murtala Mohammed by Colonel Dimka was a successful one despite the fact that Dimka was executed later.

\section{IMPLICATION}

Since knowledge construction (KC) engages in critical thinking, a critical thinker deals with questions. This questions are why's and how's. The ability to give a consummate answers to the why's and how's gives KC its derived inputs. So why does proverb have its seat at the heart of pragmatics rather than semantics and why should KC investigate it? The reason is that proverb is context-dependence and interdependence in the sense that one context can lead to another context.

Pragmatics, as a concept deals with context in sentence analysis. In the realm of pragmatics sentence structures are juxtaposed to bring out all the possibilities inherent in the structure. Since proverb is rich in context, pragmatics unfolds these intricate peculiarities of proverb.

By way of our findings we answer the questions of this study which seek to know how KC could be used in analysing proverbs in Igbo. We state thus:

a. That $\mathrm{KC}$ is suitable in analysing the Igbo proverbs since these proverbs are best analysed in their context settings and these settings are determined by a lot of factors which could be force (ex.3), neglect (ex.1\&2), possession (ex.7) or maturity (ex.9).

b. The KC goes into nitty-gritty of why things happen the way they do. This procedure is explored by various why's and how's which form the basis of critical thinking in $\mathrm{KC}$.

c. $\mathrm{KC}$ brings out the various aspects of interpretations in proverbs. This is because the more the critical thinking, the more the depth of the analysis that will emanate from the proverb in question. This enhances different ideas emanating from a particular proverb.

\section{CONCLUSION}

In the study, we set out the basic question of "how can the Knowledge Construction (KC) be used in the analysis of Igbo proverbs using pragmatic framework. Pragmatics deals with the context which necessitated the particular proverb. The context should not be tied to a particular event but must have various interpretations in order to have a wilder perspective. The $\mathrm{KC}$ is used to dig deeper in the pragmatic implication of any proverb for consideration. This it does by asking questions from different divides and also seeking to know the consequences of an opposite occurrence. For instance, why should a child who was dancing because of the meat that would follow later be denied of that meat? The $\mathrm{KC}$ finds out in that instance that rules prevail over morality. He was not part of the sharing of the meat because he was not part of it is the genuine reason why the meat was not given to him.

The KC searches into the positive and negative implication of any proverb. That is, what happens if any other thing happens? Why not and if not? Why should the ex-president GEJ give up power when people were urging him to hold onto power? Was there anything he saw that others around him did not see and could not see? Did the death of Col. Dimka stop other military officers from engaging in coup plot?

The two scenarios mentioned above emerge because KC pressed harder to interrogate their respective proverbs.

\section{REFERENCES}


[2] Austin, J.L. (1962). How to do things with words. Oxford: Oxford University Press.

[3] Bell, R.T. (1991). Translation and translating: Theory and practice. London: Longman

[4] Brown, P \& Levinson, S.L (1998). Politeness: some universal in language usage. Cambridge: Cambridge University Press.

[5] Carston, R. (2002). Thought and utterance: the pragmatic of explicit communication. Oxford: Blackwell

[6] Clark, H.H (1996). Using language. Cambridge: Cambridge University Press.

[7] Courthard,M. (1985). Introduction to discourse anaysis. New York: Longman.

[8] Dijk, T.A.V. (1977). Text and context: exploration in the semantics and pragmatics of discourse. London: Longman Group.

[9] Enwelim-Nkem, O.M. (2017). Meaning import of lecture methodology in post graduate academic discourse. In O. Taiwo, F. Ogunkeye and H. Adeniyi (eds). Revitilization of African languages. A festschrift in honour of Ozo-Mekuri Ndimele. 521-529. Linguistic Association of Nigeria.

[10] Grice, H.P. (1969). Meaning. In A.P. Martinich (ed). The philosophy of language ( $3^{\text {rd }}$ edn) $\quad 85-91 . \quad$ New $\quad$ York: Oxford University Press.

[11] Grice, H.P. (1989). Study in the ways of words. Cambridge: CUP.

[12] Knowledge construction: $21^{\text {st }}$ century competencies. A guide to planning instructions for $21^{\text {st }}$ century learners. www.wcsd21.com. Assessed 16/7/2018.

[13] Leech, G.N. (1983). Principles of pragmatics. New York: Lomgman.

[14] Levinson, S.C. (1983). Pragmatics. Cambridge: Cambridge University Press.

[15] Mbah, E.E. (2007). Prosodic morphology of reduplication in Igbo. A thesis proposal presented to the Department of Linguistics, Igbo and Other Nigerian Languages, University of Nigeria Nsukka

[16] Mey, J.L. (1993). Pragmatics: An introduction.(1 ${ }^{\text {st }}$ edn).Malden: Blackwell

[17] Mey, J.L. (2001). Pragmatics: An introduction.(2n edn).Malden: Blackwell.

[18] Ndiribe, M.O. (2015). Igbo proverbs and the image schemas: A pragmatic appraisal. The Journal of National Institute for Nigerian Languages (NILAS). 2, 3, 50-59.

[19] Ndiribe, M.O. (2016). Speech act theory. In B.M. Mbah (ed). Theories of linguistics 236- 252 Nsukka: University of Nigeria Press.

[20] Nwadike, I.U. (2009). The Igbo proverbs: a wilder perspective. Nsukka: Paschal Communication

[21] Nwoga, D.I. (1976). West African verse: an anthology .London: Longman.

[22] Obiechina, E. N. (1975). Culture, tradition and society in the West African novel. Cambridge: Cambridge University Press.

[23] Ormrod, J. E. (2008). Educational psychology: Developing learners ( $6^{\text {th }}$ edn). New Jersey: Pearson Educational Inc.

[24] Robinson, D. (2003). Performative linguistics: speaking and translating as doing things with words. London and New York: Routledge.

[25] Saaed, J. (2003). Semantics. Oxford: Blackwell publishers.

[26] Searle, J.R. (1969). Speech acts. Cambridge: Cambridge University Press.

[27] Searle, J.R. (1975). Indirect speech acts. In Cole and Morgan (eds). Syntax and semantics 3, 59-82. New York: Academic Press.

[28] Thomas, J. (1995). Meaning in interaction: An introduction to pragmatics. London: Longman.

[29] Varschueren, J. (1999). Understanding pragmatics. London and New York: Arnold publishers.

[30] Yoshitake, M. (2004). Critique of J.L. Austin's speech act theory: Decentralization of speaker-centered meaning in communication. In Kyushu communication studies 2, 27-43.

[31] Yule, G. (1985). The study of language. ( $1^{\text {st }}$ edn). Cambridge: Cambridge University Press.

[32] Yule, G. (1996). The study of language. ( $2^{\text {nd }}$ edn). Cambridge: Cambridge University Press.

Matthew Onyebuchi Ndiribe is a Nigerian from Anambra state, South-East Nigeria. Currently, he lectures at the Department of Linguistics, Igbo and other Nigerian languages, University of Nigeria, Nsukka (UNN). He holds B.A (Linguistics) in 2004, M.A in (Linguistics) (Syntax) 2009 and Ph.D also in (Linguistics) (Syntax) 2018 all from UNN. He specialises on Syntax and Semantics but has interest in other branches of linguistics like Sociolinguistics, Applied linguistics and Morphology. He has authored many articles among which are:

Ndiribe, M. O. (Argument structure of the Igbo verbs: An interlanguage analysis). Published in Journal of Linguistics, Language and Literature (Ebonyi State University, Abakaliki, Nigeria) 2018

Ndiribe, M.O. (Igbo proverbs and the Image schemas: A pragmatic Appraisal). Published in NILAS (Journal of Nigerian Languages Studies: National Institute for Nigerian Languages, Aba, Nigeria ( Vol II nos3 2015.)

Ndiribe, M.O. (Lexical semantic of planting terms in Ihiala dialect oj Igbo). Published in Journal of Linguistics, Language and Culture ( Vol. 1 nos III 2014;Nnamdi Azikiwe University (Unizik) Awka, Nigeria ) 